\title{
PELATIHAN MITIGASI GIZI BENCANA MELALUI PEMBERDAYAAN IBU-IBU PKK DIKELURAHAN PASIR PUTIH, KECAMATAN SAWANGAN, DEPOK, JAWA BARAT
}

\author{
Ikha Deviyanti Puspita ${ }^{1}$, Utami Wahyuningsih ${ }^{2}$, Widayani \\ Wahyuningtyas ${ }^{3}$ \\ ${ }^{1}$ Program Studi S1 Gizi, Universitas Pembangunan Nasional Veteran Jakarta \\ Email: ikhadevi85@gmail.com \\ ${ }^{2}$ Program Studi S1 Gizi, Universitas Pembangunan Nasional Veteran Jakarta \\ Email: utamiwahyuningsih@upnvj.ac.id \\ ${ }^{3}$ Program Studi S1 Gizi, Universitas Pembangunan Nasional Veteran Jakarta \\ Email: widayani@upnvj.ac.id
}

\begin{abstract}
The case COVID-19 in Indonesia is still high. The government has advised people to stay at home. This causes changes in daily habits that affect eating patterns and activity levels. Seeing this reality, COVID-19 health mitigation is needed. This dedication is to increase knowledge and skills regarding disaster nutrition mitigation during a pandemic, which is the main concentration on this issue. The target location for this training is Pasir Putih Village, Sawangan District, Depok, West Java, because West Java ranks 2nd in the Covid-19 case (470). The method used is to identify the problem through a preliminary study, observation and assessment of the initial knowledge and skills of the target, then determine the priority of the problem and then conduct a training program with material according to the priority of the problem. The output of this community service activity was an increase in knowledge of nutritional mitigation, including knowledge of balanced nutrition $86.6 \%$ and physical activity $80 \%$. In the nutritional mitigation behavior, there was an increase in balanced nutrition by $76.6 \%$ and physical activity by $50 \%$. The nutrition mitigation program is very important to be carried out in a sustainable manner, considering that the number of COVID-19 cases has not decreased significantly and the improvement in mitigation behavior has not increased perfectly.
\end{abstract}

Keywords: Nutrition Mitigation, Empowerment of PKK mothers, Covid-19 Pandemic

\begin{abstract}
ABSTRAK
Kasus covid-19 di Indonesia masih tinggi. Pemerintah memberikan himbauan kepada masyarakat untuk tetap di rumah. Hal ini, menyebabkan perubahan kebiasaan sehari - hari yang mempengaruhi pola makan dan tingkat aktivitas Melihat realita ini dibutuhkan mitigasi kesehatan covid-19. Pengabdian ini untuk meningkatkan pengetahuan dan keterampilan mengenai mitigasi gizi bencana selama pandemic, yang merupakan konsentrasi utama pada masalah tersebut. Target lokasi dari pelatihan ini adalah Kelurahan Pasir Putih, Kecamatan Sawangan, Depok, Jawa Barat, karena Jawa Barat rangking ke 2 kasus Covid-19 (470). Metode yang dilakukan adalah mengidetifikasi masalah melalui study pendahuluan, pengamatan dan penilaian pengetahuan dan keterampilan awal sasaran, lalu menentukan proritas masalah dan kemudian melakukan program pelatihan dengan materi sesuai prioritas masalah. Luaran kegiatan pengabdian masyarakat ini, terjadi peningkatan pengetahuan mitigasi gizi, meliputi pengetahuan gizi seimbang $86,6 \%$ dan aktifitas fisik $80 \%$. Pada perilaku mitigasi gizi terjadi peningkatan gizi seimbang 76,6\% dan aktifitas fisik $50 \%$. Program mitigasi gizi sangat penting dilakukan secara berkelanjutan, mengingat kasus covid belum turun secara significant dan peningkatan perilaku mitigasi belum meningkat secara sempurna.
\end{abstract}

Kata kunci: Mitigasi gizi, Pemberdayaan ibu-ibu PKK, Pandemi Covid-1

\section{PENDAHULUAN}

Pandemi Covid-19 di Indonesia dimulai 9 Maret 2020. Pandemi adalah skala penyebaran penyakit yang terjadi secara global di seluruh dunia namun, ini tidak memiliki sangkut paut 
dengan perubahan pada karakteristik penyakitnya. Provinsi urutan ranking tertinggi wabah covid-19 di DKI Jakarta selanjutnya Jawa Barat dan Jawa Timur.

Wabah covid-19 memberikan dampak terhadap aktivitas kesehatan, budaya, keagamaan hingga ekonomi. Terlebih sejak beberapa daerah memberlakukan kebijakan pembatasan berskala besar, krisis pun meluas. Melihat realita ini dibutuhkan mitigasi kesehatan covid-19 sebagai upaya kesehatan yang harus menjadi prioritas utama untuk dipikirkan dan dilakukan kepada masyarakat yang berakftifitas pada daerah rawan penularan covid-19 ini.

Mitigasi adalah tindakan untuk mengurangi atau meminimalkan dampak dari suatu bencana terhadap masyarakat (DKP, 2004). Salah satu kegiatan mitigasi adalah dengan kegiatan pencegahan. Kegiatan pencegahan utama pada penderita covid 19 adalah membatasi mobilisasi orang yang berisiko hingga masa inkubasi. Pencegahan lain adalah meningkatkan daya tahan tubuh melalui asupan makanan sehat, memperbanyak cuci tangan, menggunakan masker bila berada di daerah berisiko atau padat, melakukan olah raga, istirahat cukup serta makan makanan yang dimasak hingga matang dan bila sakit segera berobat ke RS rujukan untuk dievaluasi (Xiao et al, 2020). Hingga saat ini tidak ada vaksinasi untuk pencegahan primer. Pencegahan sekunder adalah segera menghentikan proses pertumbuhan virus, sehingga pasien tidak lagi menjadi sumber infeksi. Upaya pencegahan yang penting termasuk berhenti merokok untuk mencegah kelainan parenkim paru (WHO dan Kemenkes, 2020).

Upaya mitigasi gizi pada pandemic covid-19, dengan meningkatkan imunitas melalui gizi seimbang dan aktifitas fisik. Gizi merupakan hal yang menjadi perhatian penting dalam menjaga eseha kekebalan tubuh. Gizi yang memadai dan tepat diperlukan untuk agar sel berfungsi optimal. Konsumsi makanan dengan gizi seimbang dan aman, dapat meningkatkan system kekebalan tubuh serta menurunkan resiko penyakit kronis dan infeksi (Kemenkes, 2020). Selain itu, konsumsi makanan yang mengandung zat gizi berperan dalam meningkatkan imunologi juga penting, seperti vitamin A, C, E dan Zink. Dalam mendukung Imunitas tubuh, gizi yang cukup harus diimbangi dengan olah raga atau aktifitas fisik yang optimal.

Aktivitas fisik ringan lebih bermanfaat pada fungsi imunitas bila esehatan hanya melakukan aktivitas berupa duduk/tidak melakukan kegiatan apapun. Kekebalan tubuh dapat mudah ditingkatkan dengan melakukan esehat fisik/olahraga juga istirahat serta tidur cukup. Peningkatan jumlah leukosit dalam sirkulasi darah (utamanya limposit dan esehatan ) serta trombosit, dengan melakukan esehat fisik/olahraga ringan dipengaruh oleh intensitas dan durasi Latihan (Lister, 2013 ; Gleeson M, 2007). Terjadi pula peningkatan konsentrasi plasma dari berbagai substansi yang dikenal dengan efek fungsi leukosit, termasuk sitokin pada peradangan, seperti TNF- $\alpha$, makrofag inflamatori protein-1, IL-1 $\beta$; anti-inflamator sitokin IL-6, IL-10, dan IL-1-reseptor antagonist (IL-1ra); serta peningkatan kadar protein, termasuk C-reaktif protein (CRP). Mekanisme kenaikan atau penurunan imun saat esehat fisik/ olahraga dapat memberikan manfaat positif bagi esehatan dalam jangka esehat, hal ini berkaitan dengan pertahanan tubuh terhadap infeksi penyakit (Lancaster et al, 2004).

Melihat tingginya kasus covid 19 di Indonesia serta pentingnya peranan mitigasi gizi dalam meningkatkan imunitas tubuh selama pandemic, maka kami tertarik dalam melakukan kegiatan pengabdian ini

\section{METODE PELAKSANAAN PKM}

Pelaksanaan kegiatan pengabdian kepada masyarakat dibuat dengan rincian kegiatan sebagai berikut :

a. Studi Lapangan

Merupakan tahapan awal didalam menentukan obyek khalayak sasaran, dimana pengabdi berusaha memotret situasi dan kondisi yang ada dan mendiskusikan permasalahan apa yang terjadi dan juga kebutuhan dari khalayak sasaran. Pelaksanaan kegiatan studi lapangan dilakukan 
sebanyak dua kali kedatangan yang pertama adalah memotret kebutuhan atau permasalahan yang ada di desa, kemudian kedatangan selanjutnya adalah melakukan observasi langsung ke lokasi tempat rencana pengabdian kepada masyarakat akan diselenggarakan, hal ini untuk mendapatkan gambaran secara real.

\section{b. Pendekatan Pemecahan Masalah}

Setelah diketahui permasalahan yang ada, kemudian dilaksanakan penentuan topik kegiatan, pembuatan materi pelatihan dan juga penentuan jadwal kegiatan, dengan melihat situasi dan kondisi yang saat ini kurang kondusif akibat pandemik COVID.

c. Pelaksanaan Kegiatan

Pelaksanaan kegiatan dilaksanakan secara online Target khalayak sasaran adalah ibu-ibu penggerak PKK. Pelaksanaan kegiatan dibagi menjadi dua tahap yaitu :

1. Tahap awal kegiatan,

Kegiatan ini, dilakukan pre test terhadap pemahaman khalayak sasaran untuk melihat sampai sejauh mana pemahaman mereka tentang mitigasi gizi.

\section{Tahap Pelatihan}

Pelaksanaan kegiatan dua arah dengan adanya interaksi antara pengabdi dengan khalayak sasaran berupa sesi tanya jawab, praktek dan simulasi mitigasi gizi.

3. Tahap akhir kegiatan

Merupakan tahap lanjutan setelah informasi tentang pentingnya gizi untuk anak tersosialisasikan dengan baik, pada tahap ini pengabdi memberikan post test dari pemahaman materi mitigasi gizi

\section{HASIL DAN PEMBAHASAN}

\section{a. Pelaksanaan Pengabdian Masyarakat}

Kegiatan pengabdian masyarakat ini, dilaksanakan secara online melalui platform Zoom meeting. Sebelum kegiatan pemaparan materi, diberikan pre test terlebih dahulu dan diakhir kegiatan diberikan post test. Walaupun kegiatan pengabdian ini melalui daring/online, namun cukup meriah. Sasaran cukup antusias mengikutinya. Dalam mendukung keberhasilan program, pengabdi juga memberikan reward untuk peserta yang mendapat nilai tertinggi pre test, post test dan penanya terbaik.

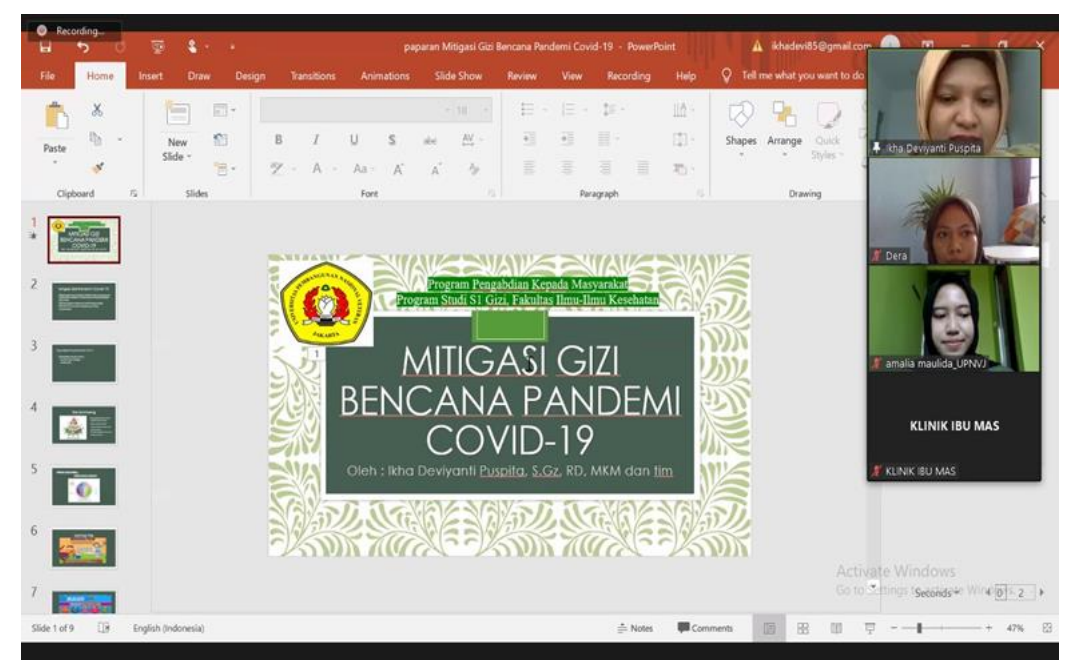

Gambar 1. Pelaksanaan Kegiatan PKM daring/online 


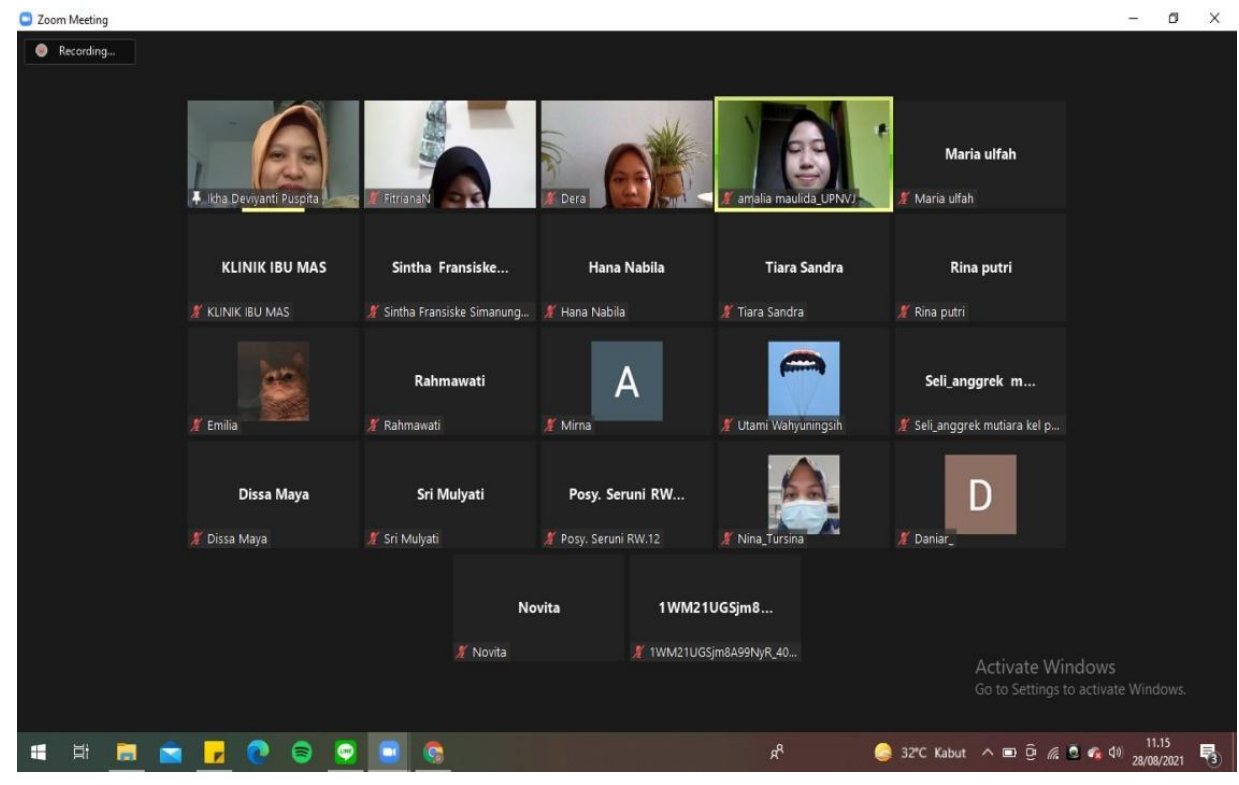

Gambar 2. Peserta Kegiatan PKM

\section{b. Karakteristik Sasaran}

Tabel 1. Gambaran karakteristik sasaran

\begin{tabular}{ccc}
\hline Karakteristik Sasaran & $\mathrm{n}$ & $\%$ \\
\hline Non Bumil & 12 & 52 \\
\hline Bumil & 11 & 47 \\
\hline Total & 23 & 100
\end{tabular}

Sasaran kegiatan pengabdian masyarakat ini adalah ibu-ibu tim penggerak PKK kelurahan Pasir Putih, Sawangan depok. Sasaran Sebagian besar adalah ibu kader posyandu. Sasaran dibedakan, ada yang sedang hamil dan tidak hamil. Hal ini, akan mempengaruhi gambaran pola konsumsi gizi seimbang yang diterapkan oleh sasaran dirumah. Kebutuhan gizi ibu hamil lebih besar dari ibu yang tidak hamil. Hal ini karena, ibu hamil mengalami peningkatan metabolisme energi. Peningkatan zat gizi selama kehamilan digunakan untuk pertumbuhan dan perkembangan janin, perubahan komposisi dan metabolisme tubuh ibu. Kekurangan zat gizi selama kehamilan dapat menyebabkan bayi lahir tidak sempurna (Andriani, 2012).

\section{c. Pengetahuan Mitigasi Gizi}

Pada pengetahuan mitigasi gizi bencana, sebagian besar sasaran mengalami peningkatan. Mitigasi gizi dibagi menjadi 2 yaitu penerapan gizi seimbang dan aktifitas fisik.

\section{Tabel 2}

Distribusi nilai perubahan pengetahuan penerapan gizi seimbang masa pandemi Covid-19

\begin{tabular}{lcc}
\hline Variabel & Pre (\%) & Post (\%) \\
\hline Komposisi Gizi seimbang & 100 & 100 \\
\hline Kebutuhan Air & 80 & 100 \\
\hline $\begin{array}{l}\text { Kebiasaan konsumsi Sayur } \\
\text { dan Buah }\end{array}$ & 40 & 60 \\
\hline Mean & 73,33 & 86,6 \\
\hline
\end{tabular}


Tabel 3

Distribusi pengetahuan aktifitas fisik masa pandemi Covid-19

\begin{tabular}{lll}
\hline Variabel & Pre (\%) & Post (\%) \\
\hline Manfaat aktifitas fisik & 100 & 100 \\
\hline Frekuensi aktifitas fisik & 30 & 60 \\
\hline Mean & 65 & 80
\end{tabular}

Pada pengetahuan gizi seimbang score lebih tinggi dibanding aktifitas fisik, hal ini kemungkinan karena paparan mengenai gizi seimbang sudah sangat tinggi. Selain dari kegiatan pengabdian masyarakat ini, paparan diperoleh dari berbagai media.

\section{d. Perilaku Mitigasi Gizi}

Tabel 4

Perilaku penerapan gizi seimbang

\begin{tabular}{lll}
\hline Variabel & Pre $(\%)$ & Post $(\%)$ \\
\hline Konsumsi Gizi seimbang & 30 & 80 \\
Konsumsi Air & 50 & 90 \\
konsumsi Sayur dan Buah & 20 & 60 \\
\hline Mean & 33,3 & 76,6
\end{tabular}

Penerapan gizi seimbang sebelum paparan mitigasi gizi, belum memenuhi ketentuan pesan gizi seimbang. Sasaran yang konsumsi gizi seimbang lengkap dalam sekali makan hanya $30 \%$, Sebagian besar sasaran mengkonsumsi makanan pokok dilengkapi dengan lauk yang banyak saja, dan makanan pokok ditambah sayur yang banyak saja. Setelah mendapatkan paparan mengeani Mitigasi gizi bencana pandemic covid, perilaku sasaran meningkat yang sudah memenuhi gizi seimbang sebesar $80 \%$. Namun masih ditemukan $20 \%$ sasaran yang mengkonsumsi makanan pokok ditambah lauk yang banyak saja.

Pada penerapan gizi seimbang pemenuhan konsumsi air putih, sasaran yang mengkonsumsi air putih sesuai kebutuhan hanya 50\%, 50\% lainnya mengkonsumsi kurang dari kebutuhan. Setelah mendapatkan paparan, sasaran merubah perilaku konsumsi air putihnya menjadi lebih baik. Sebesar $90 \%$ yang sudah mengkonsumsi minuman sesuai kebutuhan,namun masih $10 \%$ yang kurang dari kebutuhan.

Pada konsumsi sayur dan buah, sebelum mendapatkan paparan, sangat rendah sekali frekuensi konsumsinya. Yang sudah sesuai hanya, 20\%. Namun setelah mendapatkan paparan, meningkat menjadi $60 \%$. Sayur yang sering dikonsumsi responden yaitu bayam, kacang Panjang, kangkong, wortel. Buah yang sering dikonsumsi responden, yaitu jeruk, pear, pisang, pepaya, apel.

Tabel 5. Penerapan aktifitas fisik

\begin{tabular}{lll}
\hline Variabel & Pre (\%) & Post (\%) \\
\hline Frekuensi aktifitas fisik & 10 & 50 \\
\hline Mean & 10 & 50 \\
\hline
\end{tabular}

Pada penerapan aktifitas fisik sebelum paparan dan setelah paparan cukup terlihat berbeda frekuensinya. Sebelum paparan sasaran yang sudah memenuhi ketentuan aktifitas fisik hanya 10 
$\%$ dan setelah paparan $50 \%$. Sebelum mendapatkan paparan, ditemukan sasaran yang tidak pernah olah raga maupun aktifitas fizsik (20\%), 1 bulan sekali (30\%, 1-2 minggu sekali (50\%). Namun setelah mendapatkan paparan, naik menjadi 50\% yang melakukan aktifitas fisik dan olah raga 3-5 kali seminggu. $40 \%$ 1-2 minggu sekali dan $10 \% 1$ bulan sekali.

Hasil pelatihan mitigasi gizi bencana ini menunjukkan bahwa sasaran memiliki pengetahuan yang cukup baik namun untuk perilaku penerapan masih rendah. Hal ini sejalan dengan hasil penelitian Nwafor et al (2020) bahwa mayoritas ibu hamil memiliki pengetahuan yang memadai tentang tindakan pencegahan namun untuk praktik tindakan pencegahan masih buruk. Setelah dilakukan pelatihan, secara keseluruhan menunjukkan bahwa terjadi peningkatan rata-rata pengetahuan mengenai penerapan gizi seimbang dan aktifitas fisik, tidak hanya itu terjadi juga peningkatan perilaku mengenai kedua hal tersebut. Hal ini ditujunkkan oleh hasil posttest yang meningkat jika dibandingkan dengan pretest. Promosi kesehatan diketahui dapat berpengaruh pada peningkatan pengetahuan tentang gizi (Nurdin et al, 2018).

Hasil penelitian menunjukkan bahwa ibu hamil mengalami peningkatan pengetahuan dan perilaku setelah mendapatkan pendidikan gizi dan pesan gizi (Kusfriyadi, Hadi, \& Fuad, 2012). Salah satu tujuan dari pendidikan gizi adalah responden dapat mengetahui dan memahami upaya-upaya yang dapat dilakukan untuk mengatasi masalah yang mereka hadapi, dengan memanfaatkan sumber daya yang mereka miliki dan ditunjang dengan dukungan dari luar (Mubarak \& Chayatin, 2009). Hasil yang diperoleh dari kegiatan pengabdian kepada masyarakat ini adalah sasaran dapat menerima dengan baik dan berdiskusi terkait materi yang diberikan. Hal ini berkesinambungan dengan hasil pengabdian masyakarakat yang dlakukan oleh Hartini et al (2020) dan Briliannita et al (2020) yang menyebutkan bahwa sasaran memberikan respon yang positif dan diskusi dari sasaran selama pemberian materi. Pelaksanaan kegiatan pengabdian masyarakat ini sangat penting dan dibutuhkan oleh sasaran. Sasaran yaitu ibu-ibu tim penggerak PKK diharapkan menjadi agen perubahan dalam mitigasi gizi bencana melalui edukasi pada keluarga untuk mencegah serta mengurangi atau meminimalkan dampak dari suatu bencana terhadap masyarakat. Program mitigasi gizi bencana sangat penting dilakukan secara berkelanjutan mengingat kasus Covid-19 yang masih ada dan perilaku mitigasi yang masih belum baik.

\section{KESIMPULAN DAN SARAN}

Pada kegiatan pengabdian masyarakat mengenai pelatihan mitigasi gizi bencana ini menunjukkan bahwa sasaran memiliki pengetahuan yang cukup baik namun untuk perilaku penerapan masih rendah. Program mitigasi gizi sangat penting dilakukan secara berkelanjutan, mengingat kasus covid belum turun secara significant.

\section{REFERENSI}

Andriani, 2012. Peranan Gizi Dalam Siklus Kehidupan. Jakarta: Kencana Perdana Media Group Briliannita, A., Irene Marlissa, I., \& Kamaruddin, M. 2020. Pemberian Edukasi tentang Peran Telegizi Masa Pandemi Corona Virus Disease-19 (Covid-19) pada Petugas Gizi . Jurnal Abmas Negeri, 1(1), 29-36. https://doi.org/10.36590/jagri.v1i1.91

Direktorat Jenderal Pencegahan dan Pengendalian Penyakit (P2P) Kementerian Kesehatan RI. Pedoman Kesiapsiagaan Menghadapi Infeksi Novel Coronavirus (2019- nCoV). Available from: https://covid19.kemkes.go.id/downloads/\#.Xtva kWgzbIU [Accessed 30 January 2020]

Gleeson, M, 2007. Immune function in sport and exercise, Journal of Applied Physiology Published 1 August 2007 Vol. 103 no. 2, 693-699 DOI: 10.1152/japplphysiol.00008. 


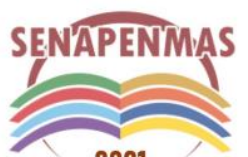

2021
Seminar Nasional Hasil Penelitian dan Pengabdian Kepada Masyarakat 2021

Pengembangan Ekonomi Bangsa Melalui Inovasi Digital Hasil Penelitian dan Pengabdian Kepada Masyarakat Jakarta, 21 Oktober 2021

Hartini, S., Winarsih, B.D., Galih, E., Nugroho, Z., Studi, P. 2020. Peningkatan Pengetahuan Perawat Untuk Perawatan Anak Penderita Kanker. Jurnal Pengabdian Kesehatan. 3(2), 141-149

Kusfriyadi, M. K., Hadi, H. and Fuad, A. 2012. Pendidikan gizi dan pesan gizi melalui short message service terhadap pengetahuan, perilaku, dan kepatuhan ibu hamil minum tablet besi. Jurnal Gizi Klinik Indonesia: 9(2), pp. 87-96.

Lancaster GI, Halson SL, Khan Q, Drysdale P, Jeukendrup AE, Drayson MT, Gleeson M. 2004. The effects of acute exhaustive exercise and intensified training on type 1/type $2 \mathrm{~T}$ cell distribution and cytokine production. Exerc Immunol Rev 10: 91-106.

Lister, I N E. 2008. Pengaruh Latihan Aerobik Intensitas Ringan dan Sedang Terhadap Jumlah Trombosit Pada Remaja Putri di Univerrsitas Prima Indonesia. Tesis. Sekolah Pascasarjana, Universitas Sumatera Utara

Liu T, Hu J, Kang M, Lin L, Zhong H, Xiao J, et al. Transmission dynamics of 2019 novel coronavirus (2019-nCoV). bioRxiv. [Preprint] 2020. [cited 14 February 2020] Available from: https://doi.org/10.1101/2020.01.25.919787

Mubarak, W. I \& Chayatin, N. 2009. Ilmu kesehatan masyarakat: teori dan aplikasi. Jakarta: Salemba Medika, 393.

Notoatmodjo, S. 2007. Promosi Kesehatan dan Ilmu Perilaku. Jakarta : Rineka Cipta

Nurdin N, Rattu A. JM, Maureen I. Punuh. 2019. Pengaruh Promosi Kesehatan terhadap Pengetahuan Peserta Didik Tentang Gizi Seimbang di SMP Muhammadiyah Ratatotok Kabupaten Minahasa Tenggara. KESMAS. 8(6):146-53.

Nwafor, J. I. et al. 2020. Knowledge and practice of preventive measures against COVID-19 infection among pregnant women in a lowresource African setting, medRxiv. Cold Spring Harbor Laboratory Press.

Sukendra, 2015. Efek Olahraga Ringan Pada Fungsi Imunitas Terhadap Mikroba Patogen : Infeksi Virus Dengue. Jurnal Media Ilmu Keolahragaan Indonesia Volume 5. Edisi 2. Desember 2015. ISSN: 2088-6802

Taslim A Nurpudji. 2006. Penyuluhan Gizi, Pemberian Soy Protein dan Perbaikan Status Gizi Penderita Tuberkulosis di Makassar. Bagian Gizi FK, Pusat studi Gizi, Pangan dan Kesehatan.

World Health Organization. Infection prevention and control during health care when novel coronavirus (Ncov) infection is suspected. [Internet] 2020. [cited 19 March 2020]. Available from:https://www.who.int/publications/i/item/106 65-331495 
Seminar Nasional Hasil Penelitian dan Pengabdian Kepada Masyarakat 2021

Pengembangan Ekonomi Bangsa Melalui Inovasi Digital Hasil Penelitian dan

Pengabdian Kepada Masyarakat

Jakarta, 21 Oktober 2021

(halaman kosong) 